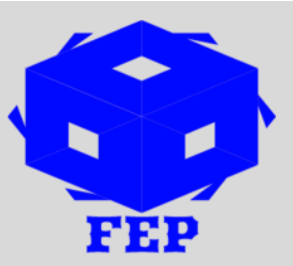

\title{
INVESGITATION ABOUT TEACHING STYLE AND LEVEL OF DEPRESSION AMONG KENYAN SCHOOL STUDENTS
}

\author{
Gilbert Koome $^{1}$, Andre Yitambe ${ }^{2}$ \\ ${ }^{1,2}$ Department of Psychology, University of Nairobi, Kenya
}

*Corresponding Author: Gilbert Koome

Article Received: 13-06-19

Accepted: $25-10-19$

Published: 05-11-19

Licensing Details: Author retains the right of this article. The article is distributed under the terms of the


(http://www.creativecommons.org/licences/by-nc/4.0/) which permits non-commercial use, reproduction and distribution of the work without further permission provided the original work is attributed as specified on the Journal open access page.

\section{ABSTRACT}

In current study, the objective was to identify the relationship between teaching style and level of depression among Kenyan junior and senior high school students. The study was conducted based on Kenyan educational panel survey. The methodology was longitudinal as students were studied in 2013 and repeatedly followed in 2017. The sampling was multistage stratified sampling and panel data analysis was used. The total sample size was 654 out of which 320 were male and 334 were female. The results showed that there were significant differences in terms of four perceived teaching style including authoritative, authoritarian, permissive, and indifferent among junior high school $\mathrm{x}^{2}(3,654=123.81, \mathrm{p}<.001)$, and senior high school, $\chi^{2}(3,654=62.91$, $\mathrm{p}<.001)$. The finding suggests that teaching style in senior high schools had different pattern in terms of effects on junior high schools. Those junior students who considered their teacher style as more authoritarian showed higher depression compare to those who considered their teacher as authoritative, permissive, and indifferent. Less depression is also observed among senior high students who perceived there to be permissive compare to other teaching style including authoritative, authoritarian, and indifferent.

Keywords: Depression, Students, Teaching Style, Kenya

\section{INTRODUCTION}

Depression is very common among adults; however, adolescents also have to face depression due to the various mental and psychological challenges which makes them vulnerable to depressive moods (Compas, Ey, \& Grant, 1993). Previous studies such as one conducted by John 
Tung Foundation (2011) showed that $18.1 \%$ of 5056 adolescents experience depression. Therefore, it is vital to give attention to adolescent depression.

Besides other factors, gender is also an individual-factor which influence adolescent depression. Studies shows that female adolescents experience greater risk of depression compare to male adolescents due to the various stressful events and self-consciousness events (Lewinsohn, et al., 1994; Kandel \& Davies, 1982). In this study, we investigate the influence of gender on depression experienced by adolescents.

Social support theory is one of the theories which explains one of the external factors causes depression. Accordingly, Malecki and Demaray (2003) defined social support as "an individual's perceptions of general support or specific supportive behaviours (available or acted on) from people in their social network, which enhances their functioning or may buffer them from adverse outcomes". Holahan and Moos (1981) pointed out that there is a negative correlation between social support and psychological maladjustment, which means perceived social support may reduce psychological distress to some extent. In the classroom context, teachers can provide critical social support to students characterized by involvement, support, and open communication and sense of security which create comfort and social, emotional, and academic competence for students (Birch \& Ladd, 1997; Pianta \&Steinberg, 1992; Khamis, 2009; Cassidy \& Shaver, 1999; Cappeliez et al, 1993; Richman, Rosenfeld, \& Bowen, 1998; Pianta,1999). The quality of interaction can be affected by teaching style directly and indirectly. Teaching style is about strategies and methods which an instructor uses in order to achieve educational goals. It is a derivation of models of parenting styles from Baumrind and has been applied to classroom context. Baumrind (1978) parenting style dimensions included as responsiveness and control, where responsiveness was about caring and warmth which a parents exhibit toward a child. Furthermore, control was about strictly rules or even criticism for misbehaviors. Baumrind developed these two dimensions to derive a four-fold classification of parenting styles: indifferent, permissive, authoritative and authoritarian. Results about the relationship between parenting style and adolescent were basically consistent, authoritative parenting style is best for children's psychological functioning and indifferent parenting style is the worst (Lambom, Mounts, Steinberg, \& Dornbusch, 1991; Radziszewska, Richardson, Dent, \& Flay, 1996; Pittman \& Chase- Lansdale, 2001; Piko \& Balazs, 2012; Milevsky, Schlechter, Netter, \& Keehn, 2007). Steinberg, Blatt, and Cauffman (2006) reported that children under four kinds of parenting style showed no difference in respect to reports of symptoms of depression in a sample of serious juvenile offenders, and Gracia and Gracia (2009) showed that in Spain the optimum style of parenting for adolescents' emotion and psychosocial adjustment is the permissive one.

As an analogue of parenting style, we used four types of teaching style in our study. Roan-Belle (2013) pointed out that indifferent teachers (low control, low responsiveness) are less demanding and less responsive and are mostly detached from the classroom. Permissive teachers (low control, high responsiveness) fosters supportive and nurturing educational environment for students, however, they often had low demandingness. Authoritarian teachers (high control, low responsiveness) assume that compliance is important than the developing student competence 
and hence minimize the importance of emotional connection with students while placing higher value on obedience and respect. Finally, authoritative teachers (high control, high responsiveness) give greater importance to building student competence and obedience, while at the same time, recognizing the importance of establishing strong emotional connection with students.

Since Pellerin (2005) applied Baumrind's typology of parenting style to high school, fewer studies conducted related to teaching style influence on students (e.g. Walker, 2008; Dever \& Karabenick, 2011). Walker (2008) tested the influence of three teaching styles including permissive, authoritarian, and authoritative on different students' outcomes. The results showed that authoritative teaching style is the highest influence on student outcomes of achievement and motivation. Dever and Karabenick (2011) tested the influence of caring for students and high academic pressure on students' interest in mathematics for school students. Results showed that authoritative teaching style is exerting highest influence on students' interest with ethnicity as moderator. So far, no studies investigated the influence of teaching style on student's depression, so this study is motivated to fulfill this literature gap. Therefore, the present study was aimed at providing a better understanding of the effect of teaching style on adolescent depression, the current study used panel data across junior and senior high schools to investigate:

(a) Whether the effect of teaching style in senior high schools has the same pattern as has been exhibited in junior high schools.

(b) What's the unique effect of teaching style in junior and senior high school on depression?

(c) Whether there is aggregate effect of junior and senior high stage teaching style on senior high students' depression.

\section{Participants}

\section{METHOD}

The study is based on Kenyan Educational Panel Survey. These students were being followed in 2013 and later in 2017. The study utilized the Kenyan Longitudinal Project supported by the Ministry of Education. The methodology is based on panel data and sampling is based on multistage stratified sampling. There were 320 male and 334 females participated in the study making total of 654 sample size.

\section{Instruments}

\section{Depression}

The measure for depression was based on 6 items. Sample items are 'in this semester, did these following things happen to you? Items included, "felt depressed", "felt lonely", "didn't want to interact with others," "wanted to scream, fight, and quarrel", "couldn't sleep well", "head numb." These 6 items assessed the self- reported frequency of depression experienced over the semester on a four-point Likert scale: never (assigned 1), sometimes (assigned 2), frequently (assigned 3), very frequently (assigned 4). All items showed good reliability as Cronbach alpha was above 0.70 . 


\section{Perceived Teaching Style}

The perceived teaching style was measured by 4 items used for developing responsiveness and control which were dimensions of perceived teaching style. These items were measured on fivepoint Likert scale. Furthermore, responsiveness and control were split by the median, respectively, where scores greater than the medians were considered high responsiveness and high control, and scores lower than the median were labelled as low responsiveness and low control. Therefore, a new variable called teaching style was formed: low responsiveness and low control represented the indifferent teaching style; high responsiveness and low control represented the permissive teaching style; low responsiveness and high control represented the authoritarian teaching style, and high responsiveness and high control represented the authoritative teaching style. Students whose scores were exactly equal to the median were then eliminated, resulting in 654 students ( 320 boys and 334 girls).

\section{RESULTS}

The results of chi-square shows that differences were observed among students across four perceived teaching style conditions including authoritative, authoritarian, permissive, and indifferent in junior high school, $\chi^{2}(3,654)=123.81, \mathrm{p}<.001$, and senior high school, $\chi^{2}$ $(3,654)=62.91, \mathrm{p}<.001$ as presented in the table below.

Table 1

Numbers of students across four perceived teaching style condition

\begin{tabular}{llllll}
\hline Teaching Style & Indifferent & Permissive & Authoritarian & Authoritative & X2 \\
\hline Junior High & 333 & 93 & 379 & 273 & $123.81^{* *}$ \\
Senior High & 324 & 390 & 307 & 233 & $62.91^{* *}$ \\
\hline
\end{tabular}

The results show that authoritative teaching style is perceived by more students in junior and senior high school. In comparison to junior high stage, more students reported perceived permissive teaching and less perceived authoritarian teaching style in senior high school which shows that senior high school students perceived more responsiveness and less control from teachers.

We used separate two-way ANOVA for investigating the difference in depression among the four groups of teaching styles at each stage including junior high stage in 2013 and senior high stage in 2017 bassed on gender and perceived teaching style and between subjects' factors. For junior high school students, the results showed significant main effect for teaching style, $\mathrm{F}(3,646)=6.432, \mathrm{p}=.000, \eta^{2}=.029$, but the main effect for gender and interaction effect between gender and teaching style were not significant, $\mathrm{F}(2,646)=3.24$, $\mathrm{p}=.077$; and $\mathrm{F}(3,646)=2.32$, $\mathrm{p}=.267$. Post hoc comparisons (Tukey's HSD, $\mathrm{p}<.05$ ) showed that junior high students who perceived teaching styles as authoritarian $(\mathrm{M}=22.92, \mathrm{SD}=4)$ were more depressed than those who perceived their teachers were indifferent $(\mathrm{M}=22.23, \mathrm{SD}=3.5)$, permissive $(\mathrm{M}=22.42, \mathrm{SD}=3.03)$ and authoritative $(\mathrm{M}=22.92, \mathrm{SD}=3.6)$. As for those students in senior high stage, the interaction effect between gender and teaching style was also not significant, $\mathrm{F}(3,646)=.024, \mathrm{p}=.995$, but the main effects for both gender and teaching style were significant, $F(2,646)=26.04$, 
$\mathrm{p}<.002, \eta^{2}=.024$; and $\mathrm{F}(3,646)=22.644, \mathrm{p}<.002, \eta^{2}=.092$, girls $(\mathrm{M}=22.25, \mathrm{SD}=3.5)$ felt more depression than boys $(\mathrm{M}=22.24, \mathrm{SD}=3.72)$ in senior high school, $\mathrm{F}(2,652)=20.488$, $\mathrm{p}=.002, \eta^{2}=.026$. Post hoc comparisons (Tukey's HSD, $\mathrm{p}<.05$ ) showed that senior high students who perceived teaching styles as permissive $(M=20.29, S D=2.77)$ were less depressed than those who perceived their teachers to be indifferent $(M=22.2694, S D=4.29)$, authoritarian $(M=23.26$, $\mathrm{SD}=4.25)$ and authoritative $(\mathrm{M}=22.03, \mathrm{SD}=3.28)$. based on different post hoc results, it can be inferred that the role of teaching style in shaping student depression varies across different age group as junior high students showed greater sensitivity to authoritarian teaching style which is leading to increased depression. Furthermore, permissive teaching style is more important in senior high stage since students reported reduced depression under this teaching style.

Table 2

ANOVA Results and Descriptive Statistics for Adolescent Depression by Teaching Style

Depression $M(S D)$

\begin{tabular}{|c|c|c|c|c|}
\hline \multirow{2}{*}{$\begin{array}{l}\text { Teaching Style } \\
\text { Junior high students }\end{array}$} & \multicolumn{4}{|c|}{ AuthoritarianAuthoritativePermissive indifferent } \\
\hline & $22.92(4)$ & $22.92(3.6)$ & $22.42(3.03)$ & $22.23(3.5)$ \\
\hline Source & $d f$ & $F$ & $\eta^{2}$ & $p$ \\
\hline Teaching style & 3 & 6.432 & 0.029 & .000 \\
\hline Gender & 2 & 3.24 & 0.000 & 0.077 \\
\hline Teaching stylexGende & & 2.32 & 0.000 & 0.267 \\
\hline Senior high students & $23.26(4.25)$ & $22.03(3.28)$ & $20.29(2.77)$ & $22.27(4.29)$ \\
\hline Source & $d f$ & $F$ & $\eta^{2}$ & $p$ \\
\hline Teaching style & 3 & 21.644 & 0.091 & .000 \\
\hline Gender & 1 & 16.04 & 0.024 & 0.000 \\
\hline Teaching stylexGende & & 0.024 & 0.000 & 0.995 \\
\hline
\end{tabular}

To examine the aggregate effect of perceived teaching style on depression, we performed an analysis of covariance (ANCOVA) with gender, perceived teaching style of 2013 and 2017, as independent variables, with score on depression of 2013 as covariate, and with score on depression of 2017 as dependent measure, see Table 3. The results indicated that there was a significant effect of gender $\mathrm{F}(1,622)=5.94, \mathrm{p}=.015, \eta^{2}=.009$. And the main effects for both perceived teaching style 2013 and perceived teaching style 2017 were conditioned by a interaction of them, $\mathrm{F}(9,622)=1.96, \mathrm{p}=.042, \eta^{2}=.028$. There was no significant interaction between gender and Perceived teaching style for $2013, \mathrm{~F}(3,622)=.80, \mathrm{p}=.49$, nor the interaction between gender and Perceived teaching style 2017, $\mathrm{F}(3,622)=.45, \mathrm{p}=.72$, nor the three-way interaction with gender, Perceived teaching style 2013, and Perceived teaching style 2017, $\mathrm{F}(8,622)=.49, \mathrm{p}=.86$. For the simple effect of senior high school teaching style, pairwise comparisons showed that for students who under indifferent teaching style in junior high school, 
after they entered senior high school, those who felt permissive teacher style were less depressive than those who felt indifferent $(\mathrm{p}=.002)$ and authoritarian $(\mathrm{p}=.011)$ teaching style. And for students under authoritarian teaching style in junior high school, after they entered senior high school, those who perceived teaching style is permissive felt less depression than those whose perception of teaching style is authoritative $(p=.006)$ and authoritarian $(p=.003)$. No other pairwise comparisons differed significantly among students who perceived teaching style as permissive and authoritative in junior high school. For the simple effect of junior high teaching style, pairwise comparisons showed that for students whose perception of teaching style was authoritarian in senior high school, among them whose perception of teaching style used to be authoritarian in junior high stage felt more depression than those under authoritative $(\mathrm{p}=.045)$ teaching style. Students whose perception of teaching style was authoritative in senior high school, among them whose perception of teaching style used to be authoritarian in junior high stage felt more depression than those under indifferent $(\mathrm{p}=.001)$ and authoritative $(\mathrm{p}=.015)$ teaching style. According to the results of simple effect, we suggested that permissive teaching style of senior high stage played a more significant role among students who under the indifferent and authoritarian teaching style in junior high school, and authoritarian teaching style of junior high stage had a long negative effect on students whose perception of teaching style were authoritarian and authoritative in high school.

Table 3

ANCOVA Results of Senior High students' Depression using their Depression Score in Junior High as the Covariate

\begin{tabular}{lllllll}
\hline Predictor & $\begin{array}{l}\text { Sum } \\
\text { Squares }\end{array}$ & of $d f$ & $\begin{array}{l}\text { Mean } \\
\text { Square }\end{array}$ & $F$ \\
\hline (Intercept) & 2256.06 & 1 & 3156.06 & 3 & .000 \\
Junior Dep & 2365.52 & 1 & 1375.53 & 144.686 & .000 \\
Gender & 56.43 & 1 & 56.43 & 5.94 & .015 \\
Junior TS & 83.28 & 3 & 37.76 & 3.93 & .033 \\
Senior TS & 244.242 & 3 & 81.41 & 8.56 & .000 \\
Gender*Junior TS & 22.84 & 3 & 7.63 & .80 & .494 \\
Gender*Senior TS & 22.64 & 3 & 4.35 & .45 & .72 \\
JuniorTS*SeniorTS & 266.64 & 9 & 18.63 & 1.96 & .042 \\
Gender*JuniorTS*Senior TS & 36.42 & 8 & 4.68 & .49 & .86 \\
Error & 5923.3 & 622 & 9.51 & &
\end{tabular}

Nots: Junior Dep = Junior high schoo students' depression; Junior TS = Teaching style in Junior high school; Senior TS

$=$ Teaching style in

Senior high school 


\section{CONCLUSIONS AND DISCUSSION}

The contribution of the study is that it contributes in the teaching style and student's outcome literature (Walker, 2008; Dever \& Karabenich, 2011). The finding suggests that teaching style in senior high schools had different pattern in terms of effects on junior high schools. Those junior students who considered their teacher style as more authoritarian showed higher depression compare to those who considered their teacher as authoritative, permissive, and indifferent. Less depression is also observed among senior high students who perceived there to be permissive compare to other teaching style including authoritative, authoritarian, and indifferent. However, this is different from literature on parenting style which suggests that authoritative parenting style was best for children's psychological functioning and indifferent parenting style has the worst result (Lambom, Mounts, Steinberg, \& Dornbusch, 1991; Radziszewska, Richardson, Dent, \& Flay, 1996; Pittman \& ChaseLansdale, 2001; Piko \& Balazs, 2012; Milevsky, Schlechter, Netter, \& Keehn, 2007). One possible explanation for this difference in nature of relationship between student and teacher compare to child and parent. That is to say, when parents make demands on their children, children will tend to accept their parents' advice or criticism, but if teachers do the same thing, it is likely to create conflict between teachers and students. Another potential is that the measurement of parenting style has been focused on mother or father in previous studies, but this study measured the perceived teaching style of the whole school, the aggregate effect of teaching style from many teachers may play a different role from the single one.

An important result of the study was that perceived teaching style had an influence on depression over time. In other words, for junior high school, the effects of authoritarian teaching style was more powerful and this effect maintained as students entered into high school especially those individuals who perceived teaching style as authoritative and authoritarian in nature.

Another important finding was that perceived teaching style had an influence on depression over time. The effect of authoritarian teaching style on depression was powerful for junior high students and the effect would be maintained after students entered into high school, especially for those whose perception of teaching style was authoritarian and authoritative in high school. It illustrated the critical and continued role of authoritarian teaching style in adolescents' depression throughout development. Besides, based on the result of simple effect, permissive teaching style in senior high school played a more significant role among students who under the indifferent and authoritarian teaching style in junior high school. These results can be explained by the aggregate effect of teaching style, the permissive teaching style (high responsiveness and low control) in senior high school can decrease the levels of depression for students who lack the responsiveness from junior high teachers, and authoritarian teaching style (high control and low responsiveness) in junior high still has a positive effect to the levels of depression for students who continue receive the high control from teachers in senior high school. Therefore, to decrease to levels of depression, teachers should give more responsiveness and less control to students no matter in junior or senior high school. 
To our knowledge, this is the first study used longitudinal data to investigate the influence of teaching style on adolescent depression. Thus, these results had several implications for theory and research, which were discussed below. (a) Although we included four kinds teaching style and explored different patterns contributing to depression, there are other predictors, mediators, and identity outcomes that should be studied in the future. For example, we focused on the role of teachers because it is a source of social support in classroom (Pianta \& Steinberg, 1992; Birch \& Ladd, 1997). However, it is also important to understand how other forms of social support (e.g. parents and peers) may influence adolescents' depression. Besides, the effect of perceived teaching style may prove more robust as it take into account both ecological variables and child characteristics that may impact the effect of teaching style. (b) Like parenting style, teaching style are culturally embedded. A useful next step for research would be determine whether adolescents in other cultures share the same patterns in our Taiwanese samples. Contrasting more family oriented or collectivistic cultures would be informative. (c) Given that the current results demonstrated the permissive teaching style is the best for psychological functioning, but other research suggested that authoritative teaching style benefits for student motivation and achievement (Pellerin, 2005; Walker, 2008), what is the best recommendation for teaching style? It is important to note that many students with high GPA experienced high pressure and negative emotion, an additional and essential extension of this work should examine what kind of teaching style is benefit for students' mental health and achievement.

Together, these results shed light on the development of adolescents' interpretation of four-fold teaching style, these four types of teaching style may play a somewhat different role in junior and senior high students' depression. We found that perceived authoritarian teaching style played a more significant role for junior high students, and this effect can last especially among those whose perception of teaching style is authoritarian and authoritative in high school. And perceived permissive teaching style was more important in senior high stage, it could decrease the levels of depression especially for those who perceived teaching style is indifferent and authoritarian in junior high school.

\section{References}

Baumrind, D. (1978). Parental disciplinary patterns and social competence in children. Youth \& Society, 9, 239-76.

Baumrind, D. (1991). The influence of parenting style on adolescent competence and substance use. The Journal of Early Adolescence, 11, 56-95.

Birch, S. H., \& Ladd, G. W. (1997). The teacher-child relationship and children's early school adjustment. Journal of School Psychology, 35, 61-79.

Brooks-Gunn, J., \& Petersen, A. C. (1991). Studying the emergence of depression and depressive symptoms during adolescence. Journal of Youth and Adolescence, 20, 115-119.

Brown, G. W., Harris, T. O., \& Eales, M. J. (1996). Social factors and comorbidity of depressive and anxiety disorders. The British Journal of Psychiatry, 168, 50-57. 
Boyd, J. H., \& Weissman, M. M. (1981). Epidemiology of affective disorders: A reexamination and future directions. Archives of General Psychiatry, 38, 1039-1046.

Cappeliez, P., \& Flynn, R. J. (1993). Depression and the social environment: research and intervention with neglected populations. Chapter 3, 73-93. Montreal, McGill- Queen.

Cassidy, J., \& Shaver, P. R. (1999). Handbook of Attachment. Chapter 15, 319-335. New York, N.Y.: Guilford.

Cohen, J, \& Cohen, P. (1983). Applied Multiple Regression/Correlation Analysis for the Behavioral Sciences. Hillsdale, NJ: Lawrence Erlbaum Associates.

Compas, B. E., Ey, S., \& Grant, K. E. (1993). Taxonomy, assessment, and diagnosis of depression during adolescence. Psychological Bulletin, 114, 323-344.

Davis, H. A. (2003). Conceptualizing the role and influence of student-teacher relationships on children's social and cognitive development. Educational Psychologist, 38(4), 207-234. doi:10.1207/S15326985EP3804_2

Dever, B. V., \& Karabenick, S. A. (2011). Is authoritative teaching beneficial for all students? A multi-level model of the effects of teaching style on interest and achievement. School Psychology Quarterly, 26, 131-144. doi:10.1037/a0022985

Finders, M. (1997). Just girls: Hidden literacies and life in junior high. New York: Teachers College Press.

Gracia, F., \& Gracia, E. (2009). Is always authoritative the optimum parenting style? Evidence from Spanish families. Adolescence, 44(173), 101-131

Holahan, C. J., \& Moos, R. H. (1981). Social support and psychological distress: a longitudinal analysis. Journal of Abnormal Psychology, 90, 365-370.

Hughes, J. N. (2012). Teacher-student relationships and school adjustment: Progress and remaining challenges." Attachment \& Human Development, 14, 319-327. doi: 10.1080/14616734.2012.672288

Hong, R. J. (2006). The relationship between the ways of disciplining which a teacher adopts at cram school and the learning pressure and academic achievement of junior high school students. Master thesis, National Kaohsiung Normal University.

Kandel, D. B., \& M. Davies. (1982). Epidemiology of depressive mood in adolescents: an empirical study. Archives of General Psychiatry, 39, 1205-1212.

Khamis, V. (2009). Classroom environment as a predictor of behaviour disorders among children with learning disabilities in the UAE. Educational Studies, 35, 27-36. doi:10.1080/03055690802648044

Lambom, S. D., Mounts, N. S., Steinberg, L., \& Dornbusch, S. M. (1991). Patterns of competence and adjustment among adolescents from authoritative, authoritarian, indulgent, and indifferent families. Child Development, 62, 1049-1065.

Lee, S. J. (2007). The relations between the student-teacher trust relationship and school success in the case of Korean middle schools. Educational Studies, 33, 209-216. 
Lewinsohn, P. M., Hops, H., Roberts, R. E., Seeley, J. R., \& Andrews, J. A. (1993). Adolescent psychopathology: I. Prevalence and incidence of depression and other DSM-III- $\mathrm{R}$ disorders in high school students. Journal of Abnormal Psychology, 102, 133-144.

Malecki, C. K., \& Demaray, M. K. (2003). What type of support do they need? Investigating student adjustment as related to emotional, informational, appraisal, and instrumental support. School Psychology Quarterly, 18, 231-252.

McGinn, L. K., Cukor, D., \& Sanderson, W. C. (2005). The relationship between parenting style, cognitive style, and anxiety and depression: Does increased early adversity influence symptom severity through the mediating role of cognitive style? Cognitive Therapy and Research, 29, 219-242.

Milevsky, A., Schlechter, M., Netter, S., \& Keehn, D. (2007). Maternal and Paternal Parenting Styles in Adolescents: Associations with Self-Esteem, Depression and Life-Satisfaction. Journal Child Family Study, 16, 39-47.

Needles, D. J., \& Abramson, L. Y. (1990). Positive life events, attributional style, and hopefulness: Testing a model of recovery from depression. Journal of Abnormal Psychology, 99, 156-165.

Pellerin, L. A. (2005). Applying Baumrind's parenting typology to high schools: toward a middle-range theory of authoritative socialization. Social Science Research, 34, 283-303.

Petersen, A. C., Compas, B. E., Brooks-Gunn, J., Stemmler, M., \& Grant, K. E. (1993). Depression in adolescence. American Psychologist, 48, 155-169.

Pianta, R. C. (1999). Enhancing relationships between children and teachers. Washington, DC, US: American Psychological Association.

Pianta, R. C., \& Steinberg, M. (1992). Teacher-child relationships and the process of adjusting to school. New Directions for Child and Adolescent Development, 57, 61-80.

Piko, B. F., \& Balazs, M. A. (2012) Control or involvement? Relationship between authoritative parenting style and adolescent depressive symptomatology.European Child Adolescent Psychiatry, 21,149-155.

Pittman, L.D., \& Chase-Lansdale, P.L. (2001). African American Adolescent Girls in Impoverished Communities: Parenting Style and Adolescent Outcomes. Journal of Research on Adolescence. 11(2),

199-224.

Radziszewska, B., Richardson, J. L., Dent, C. W., \& Flay, B. R. (1996). Parenting style and adolescent depressive symptoms, smoking, and academic achievement: Ethnic, gender and SES differences. Journal of Behavioural Medicine, 19, 289- 305.

Richman, J. M., Rosenfeld, L. B., \& Bowen, G. L. (1998). Social support for adolescents at risk of school failure. Social Work, 43, 309-323.

Rutter, M., Izard, C. E., \& Read, P. B. (1986). Depression in young people: Developmental and clinical perspectives. pp 3-30. New York, N.Y.: Guilford.

Steinberg, L., Blatt-Eisengart, I., Cauffman, E. (2006). Patterns of competence and adjustment among adolescents from authoritative, authoritarian, indulgent, and indifferent homes: a 
replication in a sample of serious juvenile offenders. Journal of Research on Adolescence, 16(1), 47-58.

Taiwan Education Panel Survey. (Wave2: Junior High School and Junior College Students, accessed April 10, 2015). http://www.teps.sinica.edu.tw.

Taiwan Education Panel Survey. (Wave4: Senior (Vocational) High School and Junior College Students, accessed April 10, 2015). http://www.teps.sinica.edu.tw.

Walker, J. M. (2008). Looking at teacher practices through the lens of parenting style. The Journal of Experimental Education, 76, 218-240.

Walker, J. M. (2009). Authoritative classroom management: How control and nurturance work together. Theory into Practice, 48, 122-129. 